\title{
Ultrasonication Treatment Improves Butterfly Pea Flower's (Clitoria ternatea L.) Anthocyanin Extraction as a Natural pH Indicator
}

\author{
Maria Wike Wijaya $^{\text {a, }}$ Valentinus Priyo Bintoro ${ }^{a,}{ }^{,}$, Sri Mulyani ${ }^{\text {a }}$, Yoga Pratama ${ }^{\text {a }}$, Nisa Arum Hidayati ${ }^{\text {a }}$ \\ ${ }^{a}$ Department of Food Technology, Diponegoro University, Jl. Prof. Soedarto Tembalang, Semarang, 50275, Indonesia \\ Corresponding author: *vepebe@yahoo.com
}

\begin{abstract}
Butterfly pea flower (Clitoria ternatea L.) is rich in anthocyanin, which can be utilized as a natural colorant. The color of anthocyanin changes based on $\mathrm{pH}$ values. Separating anthocyanin can be done by ultrasonication with ethanol solvents. This study aims to determine the effect of ultrasonication in butterfly pea flower extraction towards its yield, the value of pH extract, total anthocyanin, and color change sensitivity at different $\mathrm{pH}$ values. Butterfly pea extraction was performed with four different ultrasonication durations, i.e., 0 (without ultrasonication), 5, 10, and 15 minutes with five replications. The yield was evaluated using the gravimetry method. The value of $\mathrm{pH}$ extract was acquired using a $\mathrm{pH}$ meter. The total anthocyanin was determined by a differential pH method. Color change sensitivity was evaluated based on its red, green, and blue value (RGB). The study was conducted over 2 months. Analysis of variance (ANOVA) with a significance level of $5 \%$ and Duncan post-hoc analysis was used to evaluate the data. The results showed that the yield and total anthocyanin significantly increased as the ultrasonication duration increased and the color intensity became stronger. Whereas the value of $\mathrm{pH}$ extract slightly decreased with a longer ultrasonication duration. The best result was observed in 15 minutes of ultrasonication treatment with a yield of $71.03 \%$, pH extract value of 6.69 , and total anthocyanin of $16.99 \mathrm{mg} / \mathrm{L}$. The extract also showed high color change sensitivity in different $\mathrm{pH}$ values, indicating its potential as a good $\mathrm{pH}$ indicator.
\end{abstract}

Keywords - Anthocyanin; butterfly pea; Clitoria ternatea L.; pH indicator; ultrasonication.

Manuscript received 03 Feb. 2020; revised 18 Jul. 2020; accepted 25 Feb. 2021. Date of publication 31 Oct. 2021. IJASEIT is licensed under a Creative Commons Attribution-Share Alike 4.0 International License.

\section{INTRODUCTION}

The butterfly pea flower (Clitoria ternatea L.) is a decorative plant belongs to the Fabaceae or Leguminosae family [1]. Butterfly pea flower (BPF) has been utilized in many food applications. For example, it has been used as blue natural colorant in sticky rice in Malaysia and consumed as a vegetable in India. Those facts prove that butterfly pea is safe to consume and can be utilized as natural colorants, due to its blue color pigments in BPF that come from anthocyanin [2].

Anthocyanin is a natural dye that acts as an antioxidant found in plants. Anthocyanin is stable at $\mathrm{pH} 3.5$ and temperature $50^{\circ} \mathrm{C}$, susceptible to light and degraded at temperatures above $70^{\circ} \mathrm{C}$ [3]. Anthocyanin has a base structure 2-phenyl-benzophyrylium from flavylium salts [4]. The color of anthocyanin changes based on different $\mathrm{pH}$ values. It can be red in an acidic solution and blue in an alkaline solution. Thus, anthocyanin can be utilized as a natural $\mathrm{pH}$ indicator. However, anthocyanin degradation could occur during extracting, processing, and storaging. Some factors that affect anthocyanin stability is structure change, $\mathrm{pH}$, metal ions, oxygen, sugar, enzymes, and sulfur dioxide [5]. Volden et al. [6] revealed that high-temperature processing could decrease anthocyanin content in red cabbage to $59 \%, 41 \%$, and $29 \%$, respectively. While Brownmiller et al. [7] found that 6 months storaging could decrease total monomeric anthocyanin in blueberry purees to $>50 \%$. If the temperature rises too high, the glycosidic bond in anthocyanin will hydrolyze [8].

Due to its unstable nature, an effective extraction process is imperative to preserve anthocyanin content and quality. Common extraction techniques include maceration, percolation, and Soxhlet require a lot of time and a lot of solvents. Anthocyanin, which is sensitive towards high temperature, oxygen, and light, should ideally be extracted through a shorter and more efficient process. Ultrasonication is a method that can improve extraction efficiency. It utilizes ultrasonic waves with a frequency of $>20 \mathrm{kHz}$ that can propagate in a solid, liquid, and gas medium [9]. Ultrasonication does not affect the primary component from its sample; even ultrasonication can extract more components compared to the Soxhlet method [10]. 
Therefore, ultrasonication is a promising method to increase the anthocyanin extraction efficiency. Kusrini et al. [11] researched the activity tests of BPF extract as an anticataract agent, which was sonicated with one duration treatment, but no one has examined the improvement of BPF extract based on different ultrasonication durations. The current study employed ultrasonication treatment in BPF extraction and aimed to determine the effect of ultrasonication duration on its yield, $\mathrm{pH}$ extract value, total anthocyanin, and color change sensitivity.

\section{MAterials AND METHOD}

\section{A. Materials}

The fresh BPF (one-week-old) was obtained from Crispy Farm, Semarang, Central Java, which was harvested at 08.00$10.00 \mathrm{am}$, with ethanol $96 \%$ as the solvent. Other supporting materials were potassium chloride, natrium acetate, acetic acid, hydrogen chloride, natrium hydroxide, natrium dihydrogen phosphate for the making of the $\mathrm{pH}$ buffer, filter paper, and aluminum foil.

\section{B. Equipment}

The equipment used in this study were bath ultrasonicator (Branson, USA), vacuum rotary evaporator (Biobase, China), analytic scale (Shimadzu, Japan), pH meter (Ohaus, USA), and spectrophotometer UV-vis (Shimadzu, Japan).

\section{Experimental Design}

The study followed a completely randomized design (CRD) with four factors and five replications. Four different treatments were extraction with $0,5,10$, and 15 minutes of ultrasonication with flow chart shown in Fig. 1. The obtained data were statistically analyzed using one-way ANOVA with a significance level of 5\% and continued with Duncan posthoc whenever it was significant. The data were expressed as mean.

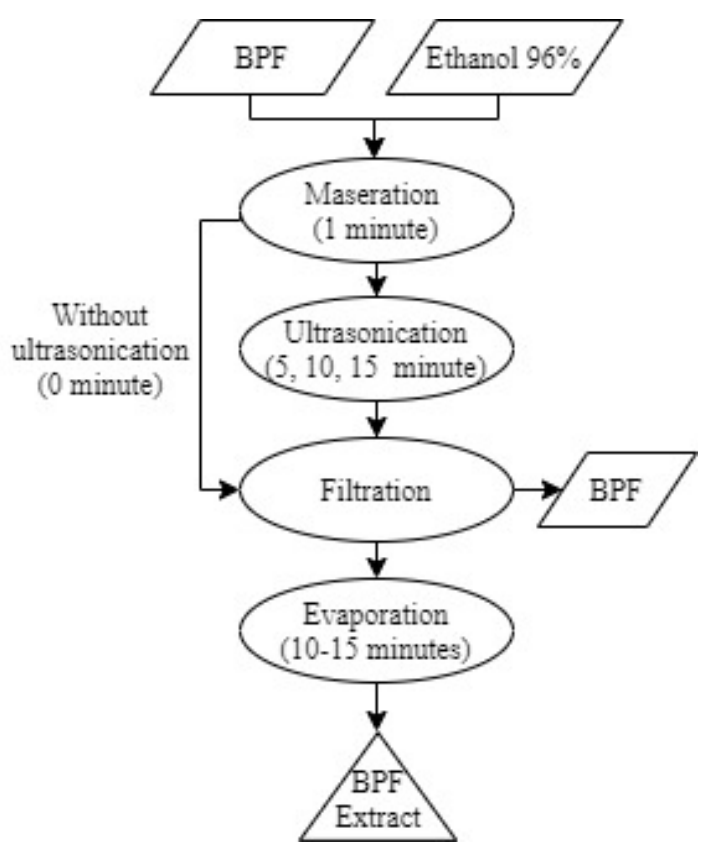

Fig. 1 Flow chart of BPF extract

\section{Extraction of $B P F$}

The fresh BPF was cut into small pieces and soaked in ethanol $96 \%$ in a ratio of $1: 10$ for 1 minute, according to Marpaung [12] and followed ultrasonication treatment at 40 $\mathrm{kHz}$. The 0 -minute treatment was carried out by macerating the BPF in ethanol for 1 minute. The extract was filtered using filter paper and evaporated at $40^{\circ} \mathrm{C}$ using a vacuum rotary evaporator until the volume was constant [13]. The concentrated extract was stored in a refrigerator at $10^{\circ} \mathrm{C}$ for further evaluation [14].

\section{E. Yield Analysis}

Yield is a ratio between the product weight to raw material weight. If the yield increases, the compound will be obtained [15]. Yield can be calculated with this formula:

$$
\text { Yield (\%) } \frac{B P F \text { extract weight }(g r)}{B P F \text { weight }(g r)}
$$

\section{F. Value of pH Extract Analysis}

The value of $\mathrm{pH}$ extract analysis was measured with a $\mathrm{pH}$ meter. The equipment was calibrated with $\mathrm{pH} 4.0,7.0$, and 10.0 buffer solutions before measurement [16].

\section{G. Total Anthocyanin Determination}

Total anthocyanin was determined with a $\mathrm{pH}$ differential method using pH 1.0 buffer and $\mathrm{pH} 4.5$ buffer solutions [17]. Buffer solutions were prepared as follows:

- $\mathrm{pH} 1$ (25 mL KCl 0,2 M and $67 \mathrm{~mL} \mathrm{HCl} \mathrm{0,2} \mathrm{M)}$

- $\mathrm{pH} 4.5$ (3 gr $\mathrm{C}_{2} \mathrm{H}_{3} \mathrm{NaO}_{2}$ diluted in aquadest until 100 $\mathrm{mL}$, then its added $\mathrm{CH}_{3} \mathrm{COOH} 0,1 \mathrm{M}$ until value of $\mathrm{pH}$ reaches 4.5 )

Each sample of $0.2 \mathrm{ml} \mathrm{BPF}$ extract was diluted in $1.3 \mathrm{ml}$ buffer solutions and its absorbance was measured at wavelengths $(\lambda)$ of 520 dan $700 \mathrm{~nm}$. The difference in absorbance was calculated with this formula:

$$
\mathrm{A}=\left(\mathrm{A}_{520}-\mathrm{A}_{700}\right)_{\mathrm{pH}} 1.0-\left(\mathrm{A}_{520}-\mathrm{A}_{700}\right)_{\mathrm{pH}} 4.5
$$

Total anthocyanin is defined as total monomeric anthocyanin, which is calculated with the below formula:

$$
\text { Total Anthocianin }(\mathrm{mg} / \mathrm{L})=\frac{A x M W \times D F \times 1000}{\varepsilon \times 1}
$$

$\mathrm{MW}=$ cyanidin-3-glucoside molecular weight $(449.2 \mathrm{~g} / \mathrm{mol})$ $\mathrm{DF}=$ dilution factor (7.5)

$\varepsilon \quad=$ molar absorptivity (26900)

\section{H. Color Change Sensitivity}

Color change in different $\mathrm{pH}$ values was observed by dropping BPF extract in $\mathrm{pH} 1.0,3.0,7.0,9.0,11.0$, and 13.0 buffer solutions for further color analysis. Red, green, and blue values (RGB) were obtained using "Color Grab" application (ver. 3.6.1). It was determined by the descriptive method to get a black and white index $\left(\mathrm{I}_{\mathrm{bw}}\right)$, which was calculated with this formula [18]:

$$
I_{b w}=\frac{\text { Red }+ \text { Green }+ \text { Blue }}{3}
$$

Each $\mathrm{pH}$ buffer was made with this method:

- pH 1.0 (25 mL KCl $0.2 \mathrm{M}$ and $67 \mathrm{~mL} \mathrm{HCl} 0.2 \mathrm{M})$

- $\mathrm{pH} 3.0\left(0.27 \mathrm{gr} \mathrm{C}_{2} \mathrm{H}_{3} \mathrm{NaO}_{2}\right.$ diluted in aquadest until 100 $\mathrm{mL}$, then added with $15 \mathrm{~mL} \mathrm{CH}_{3} \mathrm{COOH} 0.1 \mathrm{M}$ ) 
- $\mathrm{pH} 5.0$ (3 gr $\mathrm{C} 2 \mathrm{H} 3 \mathrm{NaO} 2$ diluted in aquadest until 100 $\mathrm{mL}$, then its added with $10 \mathrm{~mL} \mathrm{CH3COOH} 0.1 \mathrm{M}$ )

- $\mathrm{pH} 7.0$ (49 mL NaH2PO4 0.1 M, then added with 40 $\mathrm{mL} \mathrm{HCl} 0.1 \mathrm{M})$

- $\mathrm{pH} 9.0$ (84 mL NaH2PO4 0.1 M, then added with 0.5 $\mathrm{mL} \mathrm{HCl} 0.1 \mathrm{M})$

- $\mathrm{pH} 11.0$ (84 mL NaH2PO4 0.1 M, then added with 7.2 $\mathrm{mL} \mathrm{NaOH} 0.1 \mathrm{M})$

- $\mathrm{pH} 13.0$ (84 mL NaH2PO4 0.1 M, then added with 10 $\mathrm{mL} \mathrm{NaOH} 0.1 \mathrm{M}$ )

\section{RESULTS AND DISCUSSION}

The description of yield, the value of $\mathrm{pH}$ extract, and total anthocyanin are displayed in Fig. 2, 3, and 4. Color change sensitivity is presented in Table 1 . The table presents the data, such as captured images that represent color changes as they respond from $\mathrm{BPF}$ extract in different $\mathrm{pH}$ buffers, and present $\mathrm{I}_{\mathrm{bw}}$ values for each treatment.

\section{A. Yield}

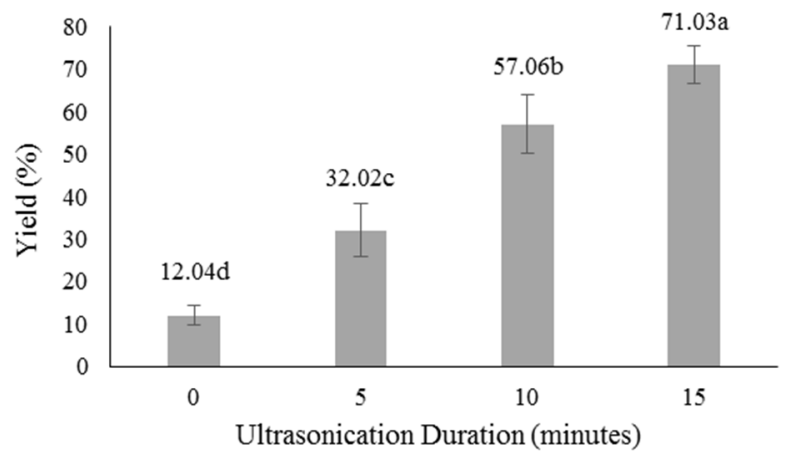

Fig. 2 The yield of BPF extract in various ultrasonication duration

Fig. 2 shows the ultrasonication duration increase caused higher extract yield. Based on the ANOVA one-way test, the significance value was 0.000 , which indicates that the treatment has a significant effect on BPF yield. There was a big difference in the 4 treatments because we used maceration in 0-min treatment to compare with ultrasonication. Therefore, material in 0-min treatment was immersed in a solvent without homogenizing and heating [19]. The solvent possibly forms a layer around the cell that could inhibit the extraction. Ultrasonic waves could break this layer due to cavitation bubbles formed during extraction [20]. Besides the duration, the yield is affected by other factors such as material and solvent ratio, solvent types, and temperature. Mehmood et al. [20] performed their ultrasonication using dried BPF and aquabidest with a ratio of $1: 15$; the obtained yield is $29 \%$. Therefore, fresh BPF and ethanol $96 \%$ with a ratio of 1:10 was proved effective; with 15 minutes, the treatment's yield reached $71.03 \%$.

Based on Fig. 2, the yield continued to increase until the 15 min treatment, indicating the treatment still optimal for anthocyanin extraction and the solvent had not reached its saturation point. However, the yield increase is less as long as ultrasonication duration increases $(5 \mathrm{~min}-0 \mathrm{~min}=20 ; 10 \mathrm{~min}-$ $5 \min =25 ; 15 \min -10 \min =14)$. Thus, there is a possibility that if the ultrasonication duration increased to $20 \mathrm{~min}$, it will be less effective because there will not be a further significant increase. Cheok et al. [24] proved that ultrasonication duration $20 \mathrm{~min}$ of anthocyanin extraction from mangosteen hull was not resulting in significant yield. Therefore, the ultrasonication of $15 \mathrm{~min}$ is the optimum duration.

Yield is the percentage of raw material used and represents the process efficiency [21]. Yield is calculated based on gravimetry, which isolates and weighs a certain compound [22]. The weighed extract was in a concentrated form. Thus, it was assumed as an isolated compound because the solvent had been evaporated. The evaporation process of BPF extract occurred in a vacuum to evaporate ethanol below its boiling point, so the evaporation process can run quickly with the lower temperature $\left(40^{\circ} \mathrm{C}\right)$ and result in a higher yield. There are two main processes in extraction, namely: washing out and diffusion [23]. While cutting the BPF into small size, the cells will be broken, and the solvent will dissolve the compounds that come out during the process called washing out. After that, the extraction will enter the diffusion stage. The gradient concentration causes compounds in cells that have the same solubility (in this case, anthocyanins are polar, same as ethanol) to be dissolved by the solvent. The solvent will bring the compound out of the cell. The solvent will stop attracting the compound when it reaches its saturation point, and the gradient concentration will not occur again.

\section{B. Value of pH Extract}

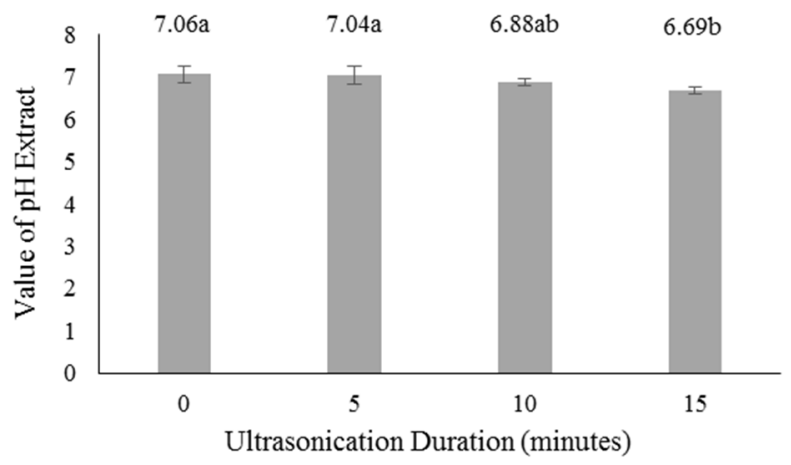

Fig. 3 The value of $\mathrm{pH}$ BPF extract in various ultrasonication duration

Value of $\mathrm{pH}$ or acidity degree is used to state the level of acidity or alkalinity of a substance. Normal value of $\mathrm{pH}$ is 7.0 , value of $\mathrm{pH}>7.0$ is alkaline, whereas value of $\mathrm{pH}<7.0$ is acid [25]. The value of $\mathrm{pH} 0$ indicates the highest acidity degree, while the value of $\mathrm{pH} 14$ indicates the highest alkaline degree. The value of $\mathrm{pH}$ can be measured using a $\mathrm{pH}$ meter that works based on electrolyte or the conductivity principle of a solution. The graph in Fig. 3 shows the ultrasonication duration increase caused by the value of $\mathrm{pH}$ extract and decrease due to more anthocyanin extracted. This was caused by the lysis of the vacuole cell wall that releases the anthocyanin and decreases the value of $\mathrm{pH}$ [26]. Some types of anthocyanin are carried acid groups, such as ternatin, which could affect the value of $\mathrm{pH}$ extract. Rodrigues et al. [27] stated that some water-soluble phenolic compounds in plant cells, which are also soluble in ethanol, could decrease the value of $\mathrm{pH}$ because they are weak acids. One of the phenol compounds present in BPF is ellagic acid. Based on the ANOVA one-way test, the significance value is 0.006 . Thus, the treatment has a significant effect on the value of $\mathrm{pH}$ BPF extract.

The decrease of $\mathrm{pH}$ extract was not affected by the solvent because ethanol is alkaline and contains hydroxide ions [28]. 
Ethanol plays a role as a quality determinant of the extract and has great power to dissolve compounds. Anthocyanin can be isolated by the extraction process, with polar solvents such as aquadest, methanol, and ethanol. However, Ramdan et al. [29] revealed that ethanol is better than aquadest. The solvent is selected by some factors, such as selectivity, solubility, density, and reactivity. The solvent should dissolve only targeted compounds. It has large power to dissolve compounds and has a large difference in density to ease the isolation of compounds. Resistance or barrier that inhibits dissolving compounds should be small, since it is affected by the amount and fineness of substance capillaries. Resistance can be done with size reduction to make the capillaries' path shorter [30]. The extracted compounds, including anthocyanin, caused a decrease in $\mathrm{pH}$ extract. The low $\mathrm{pH}$ extract is an advantage because it will stabilize the anthocyanin [8]. Li et al. [31] proved that the added acid compound to the solvent will result in lower $\mathrm{pH}$ value, such as tartaric acid and methanol. The presence of tartaric acid will stabilize the anthocyanin.

Moreover, the presence of acid compounds will extract more anthocyanin because of its ability to lysis more cell wall. For example, tartaric acid has a double role as an anthocyanin chelate agent and cell wall destroyer. However, chloride acid is only able to destroy the cell wall. Demirdoven et al. [32] performed their research about anthocyanin ultrasonication from red cabbage with ethanol and $1 \%$ formic acid. The $\mathrm{pH}$ extract that was obtained is 3.53 because they added acid to increase antimicrobe potential from anthocyanin. In this research, $\mathrm{BPF}$ extract will be used as a $\mathrm{pH}$ indicator. The value of the $\mathrm{pH}$ extract is expected to be low but tends to be neutral to keep the blue color and will not affect the color changes as can be seen in Table 1, hence this research did not add acid in ethanol.

TABLE I

COLOR CHANGE SENSITIVITY FROM BPF EXTRACT IN VARIOUS ULTRASONICATION DURATION

\begin{tabular}{|c|c|c|c|c|c|c|c|c|}
\hline \multirow{2}{*}{$\begin{array}{c}\text { Ultrasonication } \\
\text { Duration }\end{array}$} & \multicolumn{7}{|c|}{$\mathrm{pH}$ Buffer } & \multirow{3}{*}{$\begin{array}{c}\mathrm{Ibw}_{\mathrm{bw}} \\
\text { means }\end{array}$} \\
\hline & $\mathrm{pH} 1$ & $\mathrm{pH} 3$ & pH 5 & $\mathrm{pH} 7$ & pH 9 & pH 11 & $\mathrm{pH} 13$ & \\
\hline $0 \mathrm{~min}$ & & & & & & & & \\
\hline$I_{b w}$ & 199 & 203 & 180 & 193.67 & 203.33 & 210.33 & 222.67 & 201.71 \\
\hline $5 \mathrm{~min}$ & & & & & & & & $\begin{array}{l}\text { Ibw } \\
\text { means }\end{array}$ \\
\hline Ibw & 207.33 & 208.33 & 197.67 & 198 & 195 & 204.67 & 227 & 205.42 \\
\hline $10 \mathrm{~min}$ & & & & & & & & $\begin{array}{l}\mathrm{Ibw}_{\mathrm{bw}} \\
\text { means }\end{array}$ \\
\hline $\mathrm{I}_{\mathrm{bw}}$ & 211.33 & 213 & 190.33 & 187.33 & 198.67 & 205.67 & 220 & 203.76 \\
\hline $15 \mathrm{~min}$ & & & & & & & & $\begin{array}{l}\text { lbw } \\
\text { means }\end{array}$ \\
\hline Ibw & 188.67 & 210 & 195.33 & 166.33 & 179.67 & 163 & 192.33 & 185.04 \\
\hline
\end{tabular}

Note: $\mathrm{I}_{\mathrm{bw}}=$ black and white index

\section{Total Anthocyanin}

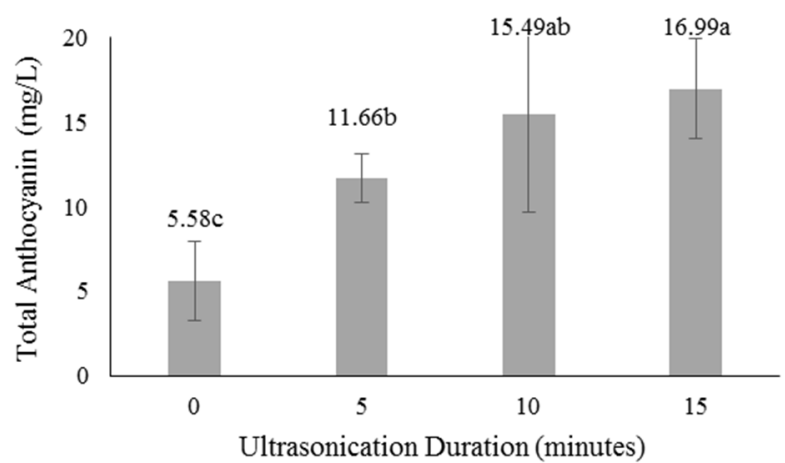

Fig. 4 Total anthocyanin of $\mathrm{pH}$ BPF extract in various ultrasonication duration

The graph in Fig. 4 shows that total anthocyanin will increase as the ultrasonication duration increases. The increase in total anthocyanin from $0 \mathrm{~min}$ to $5 \mathrm{~min}$ treatment was quite drastic because there was a difference in extraction methods. However, the increase in total anthocyanin from 10 min to 15 min treatment is not as high as the increase from 0 $\min$ to $10 \mathrm{~min}$. It is indicated that the increase in ultrasonication duration will make the solvent more saturated, therefore the extraction ability will decrease [33]. Kusrini et al. [11] did their ultrasonication from dried BPF and aquadest with a ratio of 1:62 for $15 \mathrm{~min}$, which resulted in a yield of $10.42 \mathrm{mg} / \mathrm{L}$. Therefore, fresh BPF and ethanol $96 \%$ with ratio $1: 10$ is more effective, proved by the anthocyanin yield of T3 which reached $16.59 \mathrm{mg} / \mathrm{L}$. An increase in total anthocyanin is linear with an increasing yield which can be seen in Fig. 2. Based on the ANOVA one-way test, the significance value is 0.001 , thus the different ultrasonication duration has a significant effect on the total anthocyanin of BPF extract.

The result of the hydrolysis process in the esterification reaction of one anthocyanidin (aglycone) with one or more sugar groups (glycone) [34] is anthocyanin. Some types of anthocyanin contained in BPF are ternatin, delphinidin and cyanidin-3-sophorosida. Ternatin is a polyacilation group of delphinidin derivatives that consist of delphinidin 3, 3', 5'triglucosides, bound to malonic acid, glucose, and p-coumaric acid [35]. Santoso and Estiasih [36] stated that types of anthocyanin could change if there is an addition of hydroxyl groups, formation of glycoside, or formation of methylation. The addition of hydroxyl groups will shift blue color (cyanidin to delphinidin), whereas glycoside formation and 
methylation formation will shift red color (cyanidin to peonidin). Anthocyanin consists of 3 carbon atoms that bond with 1 oxygen atom to connect 2 benzene aromatic rings. All anthocyanins have differences based on R3' and R5' bonds with aromatic rings. The anthocyanin structure base can be seen in Fig. 5.

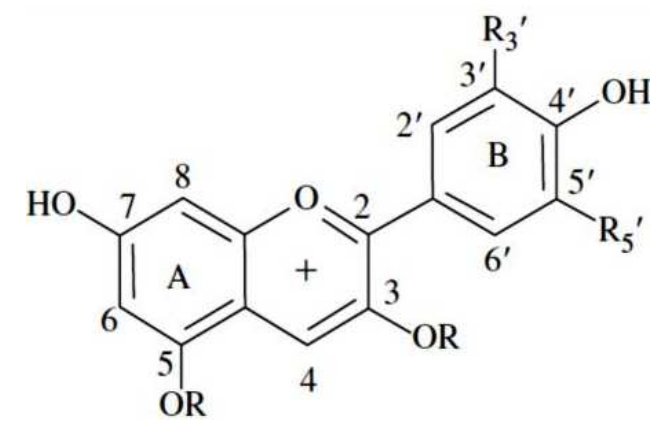

Fig. 5 R3' and R5' groups as determinants of anthocyanin types [37]

From 20 types of anthocyanin in total, each has 15 carbon atoms (C15) outside of the substitution group. R3' and R5' are substitution groups that were formed from cyanidin pigments. Those groups created by addition or reduction of hydroxyl groups, hydroxyl group position; methylation of hydroxyl groups, the number and location of sugars which are attached to the molecule; and the presence of aliphatic acids (malonic acid, acetic, malic, succinic and oxalic), or aromatic acids (p-kumaric, caffeic, ferulic, sinapic and gallic acid) in the sugar. This affects the color that will be expressed by anthocyanin and also affects its stability [38]. Anthocyanin can specifically absorb light in the absorption area of ultraviolet to violet and is stronger in the visible area of the spectrum. Anthocyanin is absorbed in a wavelength of 250 $700 \mathrm{~nm}$, with 2 peaks as the sugar group at a wavelength of around $278 \mathrm{~nm}$, and the main peak as anthocyanin around a wavelength of $500 \mathrm{~nm}$ [39].

Total anthocyanin in BPF extract was considered total cyanidin, since cyanidin is the dominant anthocyanin type in plants and is usually used as the reference in total anthocyanin calculation [40]. Different types of anthocyanin will result in different color spectrums. For example, pelargonidin has reddish-orange color, while cyanidin has a red color and delphinidin has blue color [41]. The total anthocyanin calculation is based on the absorbance of the anthocyanin in the visible area. According to Tiwari et al. [42], conjugated double bonds in the anthocyanin groups allow absorbing light in the visible light region, thus enabling the analysis of these pigments spectroscopically. The longer the conjugated double bonds in the anthocyanin structure, the stronger the colors produced in plants. If this double bond is degraded, the color intensity will decrease. The principle of total anthocyanin determination with $\mathrm{pH}$ differential is dissolving the material in a buffer of $\mathrm{pH} 1$ and $\mathrm{pH} 4.5$ to form oxonium (orange to purple) at $\mathrm{pH} 1$ and form hemiketal (colorless) at $\mathrm{pH} 4.5$. Before starting to dilute, the appropriate dilution factor for the sample is determined by ensuring the absorbance value is less than 0.8 at a wavelength of $520 \mathrm{~nm}$. A wavelength of $520 \mathrm{~nm}$ is the maximum wavelength for cyanidin-3-glucoside while a wavelength of $700 \mathrm{~nm}$ is used to correct deposits that still present in the sample.

\section{Color Change Sensitivity}

Anthocyanin is a pigment that is able to change its color in different values of $\mathrm{pH}$. This ability will represent anthocyanin sensitivity to different values of $\mathrm{pH}$ [43]. The color changing occurs because anthocyanin is present in four forms of equilibrium depending on the $\mathrm{pH}$ conditions. The four forms are cavity flavylium, carbinol pseudo-base, quinoidal base, and chalcone. Abdullah et al. [8] proved that the color of BPF extract changed to reddish-orange, red, purple, blue, green, and brownish yellow at the $\mathrm{pH}$ range of $0.04-12.00$. Those colors can be measured with various methods, one of them is RGB, which based on the calculation includes three primary colors, such as red, green, and blue. Those colors can mix to form other colors. If the highest intensity of each color is mixed, white color will be obtained. Meanwhile, the lower intensity of each color mixed will produce a black color. Measurement of the color can be affected by four factors, (1) light as a source of lighting; (2) the absorption and reflection spectrum of the illuminated product; (3) environmental conditions; and (4) the condition of the subject who sees the object [44]. Color has wavelength and light intensity parameters. If an object is illuminated, the incident ray will be absorbed (absorption), passed on (transmission), reflected (reflection), or emitted (emission).

Based on the data in Table 1, various $\mathrm{pH}$ buffers will result in the same color in each duration. The $\mathrm{pH} 1$ buffer gave a reddish color. This happened since anthocyanin formed the flavilium cation, which is the most stable form [45]. The $\mathrm{pH}$ 3 buffer gave a purple color, then turned bluish-purple at $\mathrm{pH}$ 5 buffer due to the $\mathrm{OH}^{-}$substitution, which changes the anthocyanin structure to carbinol pseudo base. More substitution of $\mathrm{OH}^{-}$will cause the color to become blue, while methylation causes the color to become red. The purple color appeared as an intermediate color from red to blue. The $\mathrm{pH} 7$ buffer did not change the color of the extract. The dominant type of anthocyanin caused the blue color of the extract in the $\mathrm{BPF}$, delphinidin [35]. The $\mathrm{pH} 9$ buffer changed the color of the extract to a greenish-blue because anthocyanin formed the quinoidal base. The extract is greener, and the blue color begins to disappear as its buffer $\mathrm{pH}$ value increases to $\mathrm{pH} 11$ because the quinoidal base degraded to a colorless chalcone. The $\mathrm{pH} 13$ buffer changes the color of the extract to yellow because all of the anthocyanin is not stable at high alkaline; therefore, it has been degraded and the color disappears [46]. The green color that appeared in $\mathrm{pH} 9$ until $\mathrm{pH} 11$ buffer is chlorophyll pigment. Rudra et al. [47] stated that chlorophyll is stable in an alkaline solution and easily degradable in an acidic solution. Otherwise, anthocyanin is stable in acid. Chlorophyll will produce chlorophyllide that bonds with magnesium ions in alkaline solution, but it will change to pheophorbide in acid solution, causes degradation in chlorophyll structure. Fasakin et al. [48] also stated that chlorophyll is easily dissolvable both in polar solvents like ethanol, methanol, acetone and nonpolar solvents like ether and chloroform.

Table 1 also shows that the color intensity is different even though the color of each treatment is the same. The average of $\mathrm{I}_{\mathrm{bw}}$ value was decreased as ultrasonication duration increased. It proved that the longer the ultrasonication duration will result in a more concentrated extract and higher anthocyanin yield. Red value, green value, blue value (RGB) 
can be averaged to determine $\mathrm{I}_{\mathrm{bw}}$ value, which states black and white intensity, a decrease in $\mathrm{I}_{\mathrm{bw}}$ value indicates that the object is getting darker and getting concentrated [49]. Meanwhile, an increase in $\mathrm{I}_{\mathrm{bw}}$ value shows the opposite because the greater the $\mathrm{I}_{\mathrm{bw}}$ value leads to the white color spectrum.

\section{CONCLUSION}

The different ultrasonication duration in the extraction of BPF significantly affects the yield, value of $\mathrm{pH}$ extract, and total anthocyanin. The color becomes more concentrated as the ultrasonication duration increases. Thus, the color changes at various $\mathrm{pH}$ values are more pronounced. The best result was obtained in 15 minutes of ultrasonication with a yield of $71.03 \%, \mathrm{pH}$ extract value of 6.69 , and total anthocyanin of $16.99 \mathrm{mg} / \mathrm{L}$. It also has high color change sensitivity in different $\mathrm{pH}$ values, hence indicating its potential to be used as a natural $\mathrm{pH}$ indicator.

\section{ACKNOWLEDGMENT}

The authors are grateful to the Diponegoro University for funding this research.

\section{REFERENCES}

[1] A. Tantituvanont, P. Werawatganone, P. Jiamchaisri and K Manopakdee, "Preparation and stability of BPF color extract loaded in microparticles prepared by spray drying", Thailand J. Pharma. Sci., vol. 32 , no. 1 , pp. 59-69, 2008.

[2] K. Kungsuwan, K. Singh, W. Phetkao, and Utama-ang, "Effects of pH and anthocyanin concentration on color and antioxidant activity of Clitoria ternatea extract", J. of Food and Applied Biosci., vol. 2, no. 1, pp. 31-46, 2014.

[3] N. Noda, S. Yoshioka, S. Kishimoto, M. Nakayama, M. Douzono, Y. Tanaka and R. Aida, "Generation of blue chrysanthemums by anthocyanin B-ring hydroxylation and glucosylation and its coloration mechanism", J. of Sci. Advances, vol. 3, no. 7, pp. 110-120, 2017, DOI: $10.1126 /$ sciadv.1602785.

[4] M. Trojak and E. Skowron, "Role of anthocyanins in high-light stress response", J. of World Scientific, vol. 81, no. 2, pp. 150-168, 2017.

[5] D. M. Aguilar, A. E. Regules, J. D. Ramírez, M. C. Pérez and J. WeltiChanes, "Color and chemical stability of spray-dried blueberry extract using mesquite gum as wall material", J. of Food Composition and Analysis, vol. 24, no. 6, pp. 889-894, 2011, DOI: https://doi.org/10.1016/j.jfca.2011.04.012.

[6] J. Volden, I. Grethe, A. Borge, B. Gunnar, and H. Ingrid, "Effect of thermal treatment on glucosinolates and antioxidant-related parameters in red cabbage (Brassica oleracea L. ssp. capitata f.rubra)", Food Chem., vol. 109, no. 3, pp. 595-605, 2008. DOI: https://doi.org/10.1016/j.foodchem.2008.01.010.

[7] C. Brownmiller, L. R. Howard, and R. L. Prior, "Processing and storage effects on monomeric anthocyanins, percent polymeric colour, and antioxidant capacity of processed blueberry products", J. of Food Sci., vol. 5, no. 73, pp. 72-79, 2008. DOI: $10.1111 / \mathrm{j} .1750-$ 3841.2008.00761.x.

[8] R. Abdullah, P. M. Lee, and K. H. Lee, "Multiple color and pH stability of floral anthocyanin extract: Clitoria ternatea", in Intl. Conference on Sci. and Social Research, pp. 254-258, 2010. DOI: 10.1109/CSSR.2010.5773778.

[9] M. H. Dehghani, "Removal of cyanobacterial and algal cells from water by ultrasonic waves-A review", J. of Molecular Liq., vol. 22, no. 2, pp. 1109-1114, 2016.

[10] D. K. Cameron and W. Y. Jane, "Application of protease and highintensity ultrasound in corn starch isolation from degermed corn flour", J.l of Food Sci., vol. 83, no. 5, pp. 505-509, 2006. DOI: https://doi.org/10.1094/CC-83-0505.

[11] E. Kusrini, D. Tristantini dan N. Izza, "Uji aktivitas ekstrak bunga telang (Clitoria ternatea L.) sebagai agen anti katarak", J. Jamu Indonesia, vol. 2, no. 1, pp. 30-36, 2017.

[12] T. A. B. Marpaung, "Efektivitas Konsentrasi Asam Sitrat pada Ekstraksi Pigmen Antosianin dari Bunga Telang (Clitoria terrnatea) dan Aplikasinya Pada Permen Jelly Sirsak", Disertasi Program Doktor, Universitas Muhammadiyah Malang. Indonesia, 2018.

[13] E. F. Riyanto dan R. Suhartati, "Daya hambat ekstrak etanol bunga telang (Clitoria ternatea L) terhadap bakteri perusak pangan", J. Ilmu Keperawatan, Analis Kesehatan dan Farmasi, vol. 19, no. 2, pp. 218225, 2019. DOI: http://dx.doi.org/ 10.36465/jkbth.v19i2.500.

[14] H. Hariadi, M. Sunyoto, B. Nurhadi and A. Karuniawan, "Comparison of phytochemical characteristics pigment extract sweet purple potatoes powder (Ipomoea batatas L) and clitoria flower (Clitoria ternatea) as natural dye powder", J. of Pharmacognosy and Phytochem., vol. 7, no. 4, pp. 3420-3429, 2018.

[15] D. Agustin dan Ismiyati, "Pengaruh konsentrasi pelarut pada proses ekstraksi antosianin dari bunga kembang sepatu", J. Konversi, vol. 4, no. 2, pp. 9-16, 2015.

[16] AOAC, Official Method of Analysis of the AOAC, 14th ed., Virginia: AOAC. Inc, 2005.

[17] J. Lee, J. Durst, and Wrolstad, "Determination of total monomeric anthocyanin pigment content of fruit juices, beverage, natural colorants, and wines by the $\mathrm{pH}$ differential method", Journal of $A O A C$ International, vol. 88, no. 5, pp. 1269-1278, 2005.

[18] Evaardinna, Sulhadi dan B. Aji, "Analisis RGB Pigmen Dari Kulit Buah Naga" in Prosiding Pertemuan Ilmiah XXX HFI Jateng \& DIY, pp. 142-146, 2016.

[19] M. Gallo, A. Formato, D. Ianniello, A. Andolfi, M. Ciaravolo, and D. Naviglio, "Supercritical fluid extraction of pyrethrins from pyrethrum flowers (Chrysanthemum cinerariifolium) compared to traditional maceration and cyclic pressurization extraction", J. of Supercritical Fluids, vol. 119, no. 3, pp. 104-112, 2017. DOI: https://doi.org/10.1016/j.supflu.2016.09.012.

[20] A. Mehmood, M. Ishaq, L. Zhao, S. Yaqoob, B. Safdar, M. Nadeem, and C. Wang, "Impact of ultrasound and conventional extraction techniques on bioactive compounds and biological activities of blue butterfly pea flower (Clitoria ternatea L.)", J. of Sonochem., vol. 51, pp. 12-19, 2019.

[21] L. Malanggi, M. Sangi, dan J. Paendong, "Penentuan kandungan tanin dan uji aktivitas antioksidan ekstrak biji buah alpukat (Persea americana Mill.)", J. MIPA, vol. 1, no. 1, pp. 5-10, 2012. DOI: https://doi.org/10.35799/jm.1.1.2012.423.

[22] W. R. Kelly, B. S. MacDonald, and W. F. Guthrie. "Gravimetric approach to the standard addition method in instrumental analysis", $J$. Analytical Chem., vol. 80, no. 16, pp. 6154-6158, 2008. DOI: https://doi.org/10.1021/ac702437f.

[23] Y. C. Cheung and J. Y. Wu. "Kinetic models and process parameters for ultrasound-assisted extraction of water-soluble components and polysaccharides from a medicinal fungus", J. Biochem. Engineering, vol. 79, no. 2, pp. 214-220, 2013.

[24] C. Y. Cheok, N. L. Chin, Y. A. Yusof, R. A. Talib, and C. L. Law, "Optimization of total monomeric anthocyanin (TMA) and total phenolic content (TPC) extractions from mangosteen (Garcinia mangostana Linn.) hull using ultrasonic treatments", J. of Industrial Crops and Products, vol. 50, no. 1, pp. 1-7, 2013. DOI: 10.1016/j.indcrop.2013.07.024.

[25] M. A. Naas, M.R Kirom dan R. F Iskandar, "Pengaruh pH terhadap produktivitas gas di reaktor anaerob dengan substrat limbah makanan", J. of Engineering, vol. 3, no.3, pp. 100-110, 2016.

[26] L. Simanjuntak, C. Sinaga, dan Fatimah, "Ekstraksi pigmen antosianin dari kulit buah bunga merah (Hylocereus polyrhizus)", J. Teknik Kimia USU, vol. 3, no. 2, pp. 25-29, 2014.

[27] S. Rodrigues, F.A.N. Fernandes, E.S. de Brito, A.D. Sousa and N. Narain, "Ultrasound extraction of phenolics and anthocyanins from jabuticaba peel”, J. of Industrial Crops, vol. 69, no. 1, pp. 400-407, 2015. DOI:10.1016/j.indcrop.2015.02.059.

[28] S. Setiawan, F. Restuhadi, dan F. Hamzah, "Pengembangan etanol semi padat dengan pencampuran minyak jelantah", J. Fakultas Pertanian, vol. 2, no. 2, pp. 1-10, 2015.

[29] U. M. Ramdan, Y. Aryanti dan W. Mulyana, "Efektivitas konsentrasi etanol untuk pewarna alami kembang telang (Clitoria ternatea L.) dan aplikasinya sebagai alternatif indikator asam basa", J. Kesehatan Bakti Tunas Husada., vol. 17, no. 1, pp. 33-40, 2017. DOI: http://dx.doi.org/10.36465/ jkbth.v17i1.208.

[30] Bernasconi, G., H. Gester, H. Stauble, and E. Schneiter, Teknologi Kimia, jilid 2. Jakarta : Pradaya Paramita, 1955.

[31] Z. J. Li, L. Tang, P. Liu and R. X. Sun, "Optimization of anthocyanin extraction from roses by using response surface methodology", J. of Food Sci. and Tech., vol. 11, no. 2, pp. 200-210, 2009. DOI: 10.3390/ijms13056292. 
[32] A. Demirdoven, S. Karabıyıklı, K. Tokatlı and N. Öncül, "Inhibitory effects of red cabbage and sour cherry pomace anthocyanin extracts on food borne pathogens and their antioxidant properties", J. of Food Sci. and Tech., vol. 63, no. 1, pp. 8-13, 2015. DOI:10.1016/j.lwt.2015.03.101.

[33] Z. Yang and W. Zhai, "Optimization of microwave-assisted extraction of anthocyanins from purple corn (Zea mays L.) cob and identification with HPLC-MS", J. of Innovative Food Sci. and Emerging Tech., vol. 11, no. 3, pp. 470-476, 2010. DOI: https://doi.org/10.1016/j.ifset.2010.03.003

[34] V. Gowd, Z. Jia, and W. Chen, “Anthocyanins as promising molecules and dietary bioactive components against diabetes-a review of recen advances", J. of Trends in Food Sci. and Technology, vol. 68, no. 1, pp. 1-13, 2017. DOI:10.1016/j.tifs.2017.07.015.

[35] Y. Shen, D. L. Zeng, H. Zhang, F. Prinyawiwatkul, M. Alonso, and Z. $\mathrm{Xu}$, "Butterfly pea (Clitoria ternatea) seed and petal extracts decreased HE p-2 carcinoma cell viability", J. of Food Sci. and Tech., vol. 51, pp. 8 , pp. $1860-1868,2016$. DOI: $10.1111 /$ ijfs. 13158 .

[36] W. E. A. Santoso dan T. Estiasih, "Kopigmentasi ubi jalar ungu (Ipomoea batatas var. Ayamurasaki) dengan kopigmen na-kaseinat dan protein whey serta stabilitasnya terhadap pemanasan", J. Pangan dan Agroindustri, vol. 2, no. 4, pp. 121-126, 2014

[37] M. Priska, N. Peni, L. Carvallo dan Y. Ngapa, "Antosianin dan pemanfaatannya”, J. Cakra Kimia, vol. 6, no. 2, pp. 79-97, 2013.

[38] S. Kamiloglu, E. Capanoglu, C. Grootaert and J. Camp, “Anthocyanin Absorption and Metabolism by Human Intestinal Caco-2 Cells-A Review”, Intl. J. of Molecular Sci., vol. 16, pp. 21555 - 21574, 2015.

[39] D. Pratiwi, F. Nurosyid, A. Supriyanto and R. Suryana, "Efficiency enhancement of dye-sensitized solar cells (DSSC) by addition of synthetic dye into natural dye (anthocyanin)", In IOP Conference Series: Materials Sci. and Engineering, vol. 176, no. 1, pp. 101-112, 2017. DOI:10.1088/1757-99X/176/1/012012.

[40] X. Liu, H. Sun, M. Zhang, and J. Chen, "Optimisation of aqueous twophase extraction of anthocyanins from purple sweet potatoes by response surface methodology", J. Food Chem., vol. 141, no. 1, pp. 3034 - 3041, 2013. DOI: 10.1016/j.foodchem.2013.05.119.
[41] T. N. Pham, D. Nguyen, P. Van Thinh, X. T. Quang, dan H. V. Bach, L. G, "Extraction of anthocyanins from Butterfly pea (Clitoria ternatea L.) in Southern Vietnam: Response surface modeling for optimization of the operation conditions", J. of Materials Sci. and Engineering, vol. 542, no. 1, pp. 12-32, 2019. DOI: 10.1088/1757 $899 \mathrm{X} / 542 / 1 / 012032$

[42] B. K. Tiwari., C.P. O'donnell, A. Patras, N. Brunton and P.J. Cullen, "Anthocyanins and color degradation in ozonated grape juice", $J$. of Food and Chem.l Toxicology, vol. 47, no. 11, pp. 2824-2829, 2009. DOI: 10.1016/j.fet.2009.09.001.

[43] I. Choi, J. Y. Lee, M. Lacroix and J. Han, "Intelligent pH indicator film composed of agar/potato starch and anthocyanin extracts from purple sweet potato", J. of Food Chem., vol. 218, no. 1, pp. 122-128, 2017. DOI: 10.1016/j.foodchem.2016.09.050.

[44] N. Andarwulan, F. Kusnandar, dan D. Herawati, Analisis Pangan, Jakarta : Dian Rakyat, 2011.

[45] M. Terahara, T. Matsui, Y. Osajima, N. Saito, K. Toki, and T. Honda, "Five new anthocyan ins, ternatins A3, B4, B3, B2 and 02, from elitaria trenalea flower", J. of Nat. Prod, vol. 59, no. 1, pp. 139-144, 1996. DOI: $10.1021 / \mathrm{np} 960050 \mathrm{a}$

[46] J. Alvionita, D. Darwis, dan M. Efdi. "Ekstraksi dan identifikasi senyawa antosianin dari jantung pisang raja (Musa paradisica L.) serta uji aktivitas antioksidannya" J. Riset Kimia, vol 9, no. 2, pp. 21-27, 2016. DOI: $10.25077 /$ jrk.v9i2.284

[47] S. G. Rudra, B. C Sarkar, and U. S. Shivhare, "Thermal degradation kinetics of chlorophyll in pureed coriander leaves", J. of Food and Bioprocess Tech., vol. 1, no. 1, pp. 91-99, 2008. DOI: https://doi.org/10.1007/s1 1947-007-0016-z.

[48] C. F. Fasakin, C. C. Udenigwe and R. E. Aluko, "Antioxidant properties of chlorophyll-enriched and chlorophyll-depleted polyphenolic fractions from leaves of Vernonia amygdalina and Gongronema latifolium", J. of Food Research Intl., vol. 44, no. 8, pp. 2435-2441, 2011. DOI: 10.1016/j.foodres.2010.12.019.

[49] S. Zhang and P. Huang, "High-resolution, real-time 3D shape acquisition", In Conference on Computer Vision and Pattern Recognition. pp. 28-38, 2004. DOI: 10.1016/j.tifs.2017.07.015. 